\title{
Forming and Interpreting Gradients in the Early Xenopus Embryo
}

\author{
James C. Smith \\ National Institute for Medical Research, The Ridgeway, Mill Hill, London NW7 1AA \\ Correspondence: jim.smith@nimr.mrc.ac.uk
}

The amphibian embryo provides a powerful model system to study morphogen gradients because of the ease with which it is possible to manipulate the early embryo. In particular, it is possible to introduce exogenous sources of morphogen, to follow the progression of the signal, to monitor the cellular response to induction, and to up- or down-regulate molecules that are involved in all aspects of long-range signaling. In this article, I discuss the evidence that gradients exist in the early amphibian embryo, the way in which morphogens might traverse a field of cells, and the way in which different concentrations of morphogens might be interpreted to activate the expression of different genes.

$T_{\text {tito }}^{\text {he }}$ he idea that a morphogen gradient activates the expression of different genes at different concentrations was perhaps stated most clearly by Wolpert's French flag model, in which a graded signal activates the expression of "blue," "white," and "red" genes at high, intermediate, and low concentrations (Wolpert 1969). Since that original work, great progress has been made in identifying morphogens and their target genes and it is now clear that the spatial pattern of gene expression in the developing embryo is frequently established by graded signals of this sort. But many questions remain, and in particular little is known about how gradients are established in the embryo with the necessary precision and how cells interpret different concentrations of morphogen to activate different genes. I discuss these issues with respect to mesoderm induction in the developing amphibian embryo.

\section{MESODERM INDUCTION}

The mesoderm of the developing amphibian embryo is derived from cells in the equatorial region of the mid- to late blastula (Vogt 1929) (Fig. 1A,B). The mesoderm forms in this position in response to a signal derived from the vegetal hemisphere of the embryo, as first shown in the urodele Ambsytoma mexicanum (Nieuwkoop 1969), and then 2 years later in the anuran Xenopus laevis (Sudarwati and Nieuwkoop 1971). By isolating the animal hemispheres of amphibian embryos at different stages, Nieuwkoop was able to show that the equatorial region receives a mesoderm-inducing signal beginning at the early blastula stage, and that animal pole tissue that is normally out of range of the signal can be induced to form mesoderm by juxtaposition with blastomeres of the vegetal hemisphere (Fig. 1C,D).

Editors: James Briscoe, Peter Lawrence, and Jean-Paul Vincent

Additional Perspectives on Generation and Interpretation of Morphogen Gradients available at www.cshperspectives.org

Copyright (C) 2009 Cold Spring Harbor Laboratory Press; all rights reserved; doi: 101101/cshperspect.a002477

Cite this article as Cold Spring Harb Perspect Biol 2009;1:a002477 
J.C. Smith

A

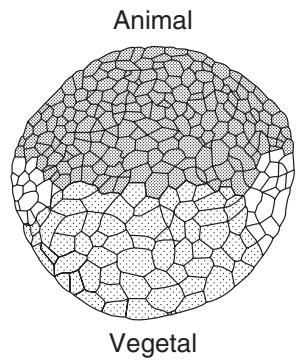

C

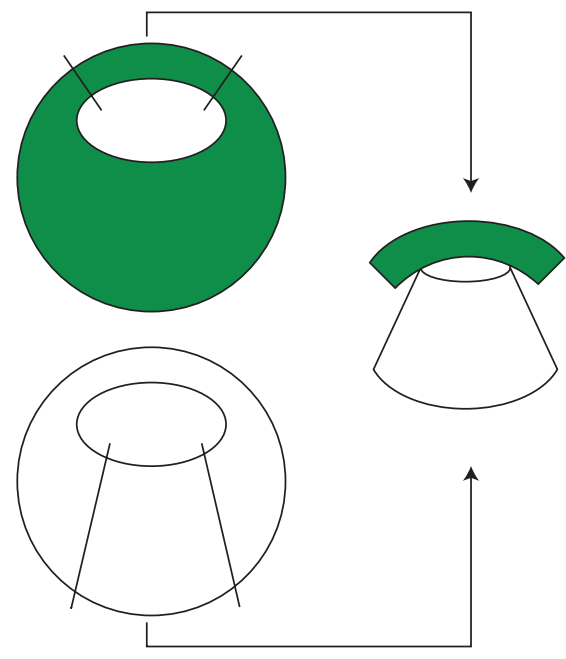

B

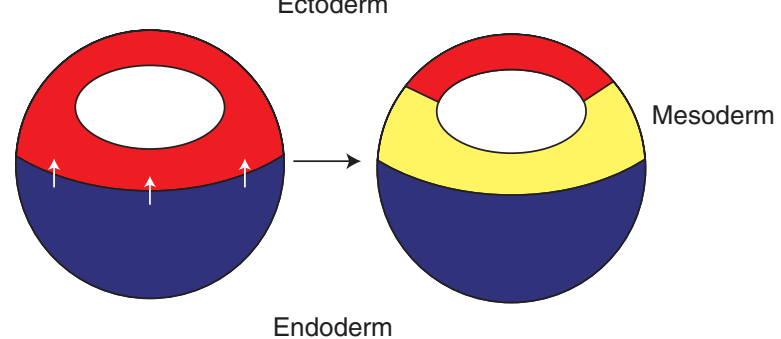

D

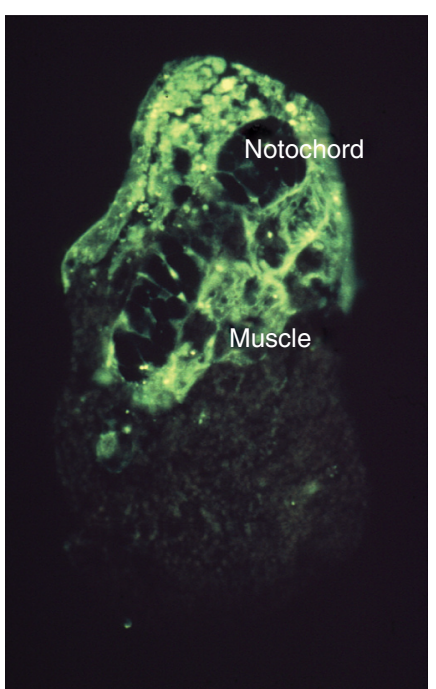

Figure 1. Mesoderm induction. (A) Drawing of a Xenopus embryo at the midblastula stage (Nieuwkoop 1956). The animal hemisphere is to the top and the vegetal hemisphere to the bottom. The mesoderm forms in the equatorial region of the embryo between the two. (B) Mesoderm induction. A signal from the vegetal hemisphere of the embryo (white arrows) causes equatorial cells to form mesoderm. $(C)$ Demonstration of mesoderm induction. Animal pole tissue derived from an embryo uniformly labeled with a fluorescent lineage label is juxtaposed with vegetal pole tissue from an unlabeled embryo and the resulting conjugate is cultured for 3 days. (D) The result of such an experiment. The fluorescently labeled tissue differentiates as notochord and muscle rather than epidermis. Photograph courtesy of Les Dale and Jonathon Slack.

These early experiments were followed by further work indicating that mesoderm induction is not an all-or-none process, but a quantitative one in which dorsal vegetal tissue provides a stronger signal than does lateral or ventral vegetal tissue (Boterenbrood and Nieuwkoop 1973). Thus, dorsal tissue was able to induce large amounts of predominantly dorsal tissue, which included notochord and muscle and lacked primordial germ cells, whereas the lateral and ventral vegetal cells induced blood, and many primordial germ cells, and no notochord and little muscle. The investigators argued that these differences represented a quantitative, rather than a qualitative, difference in the inducing activities of the different regions of the vegetal hemisphere because all regions are able to induce similar amounts of pronephros and Wolffian duct.

These conclusions reached by Nieuwkoop and colleagues were confirmed and extended in Xenopus laevis in experiments making use 
of reliable cell lineage markers and regionspecific markers (Dale et al. 1985; Smith et al. 1985), and it soon became clear that mesoderm induction is a quantitative process.

\section{MESODERM INDUCING FACTORS}

The next significant step in our understanding of mesoderm induction came with the identification of mesoderm-inducing factors: molecules which could cause isolated animal pole regions to differentiate into mesoderm in the absence of vegetal pole material. These molecules fell into two classes. The first comprised members of the transforming growth factor type $\beta$ (TGF- $\beta$ ) family, including activin (Albano et al. 1990; Asashima et al. 1990; Smith et al. 1990), Vg1 (Weeks and Melton 1987; Birsoy et al. 2006), derrière (Sun et al. 1999), and the Xenopus nodal-related proteins Xnr1, -2, -4, -5, and -6 (Jones et al. 1995; Joseph and Melton 1997; Takahashi et al. 2000). The second included members of the fibroblast growth factor family, such as FGF2 (Kimelman and Kirschner 1987; Slack et al. 1987) and FGF4 (Isaacs et al. 1992). In this article, we consider only members of the TGF- $\beta$ family: Although distinctions of this sort may be a little simplistic (Fletcher and Harland 2008), TGF- $\beta$ s appear to play the major role in initiating mesoderm formation, whereas FGF family members may be more involved in maintaining mesodermal identity (Kroll and Amaya 1996; Heasman 2006).

\section{EVIDENCE FOR GRADED SIGNALING: IN VITRO}

The first indication that these mesoderminducing factors might act in a concentrationdependent fashion came from experiments in which isolated Xenopus laevis animal pole regions were treated with different concentrations of partially purified activin (Green et al. 1990). The results of these experiments were reminiscent of those performed by Nieuwkoop and colleagues (Boterenbrood and Nieuwkoop 1973), in that higher concentrations of activin induced the formation of notochord and muscle, whereas lower levels resulted in the formation of ventral and lateral cell types such as mesenchyme and mesothelium. Interestingly, increasing time of exposure to a single concentration of activin had a similar dose-dependent effect, with more dorsal structures forming with increased duration (Green et al. 1990).

The ability of (presumably) a single molecule to induce different cell types at different concentrations could be interpreted in terms of positional information (Wolpert 1969), but analysis of the results in terms of this model was hampered by the fact that clear "thresholds" (Lewis et al. 1977) were not observed; there was, as in Nieuwkoop's experiments, considerable overlap in the tissues that were formed at different activin concentrations (Green et al. 1990). In an attempt to overcome this difficulty, two changes were made to the experimental design, and in addition it became possible to use purified preparations of activin (Smith et al. 1990). In the first change to the experimental design, animal pole regions were disaggregated to create a single cell suspension, thereby ensuring that activin had equal access to all cells. In the second, the inductive effects of activin were monitored by measuring gene activation rather than by using histological techniques, thereby allowing a more quantitative approach. The results obtained in this way were more promising, with different genes being activated at different concentrations of activin, with threefold differences in activin concentration being sufficient to yield a qualitative change in gene expression (Green and Smith 1990; Green et al. 1992; Green et al. 1994).

Of the genes that respond differentially to different concentrations of activin, two are worth discussing at length: Xbra (Smith et al. 1991) and goosecoid (Cho et al. 1991) (Fig. 2A-C). The former encodes a member of the $\mathrm{T}$ box family of transcription factors (Naiche et al. 2005) and is expressed throughout the marginal zone of the Xenopus embryo from the late blastula stage (Smith et al. 1991). Goosecoid encodes a homeodomain protein that is expressed in the dorsal mesendoderm of the Xenopus late blastula and early gastrula 
J.C. Smith

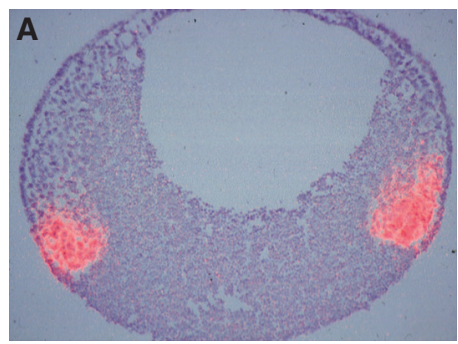

D
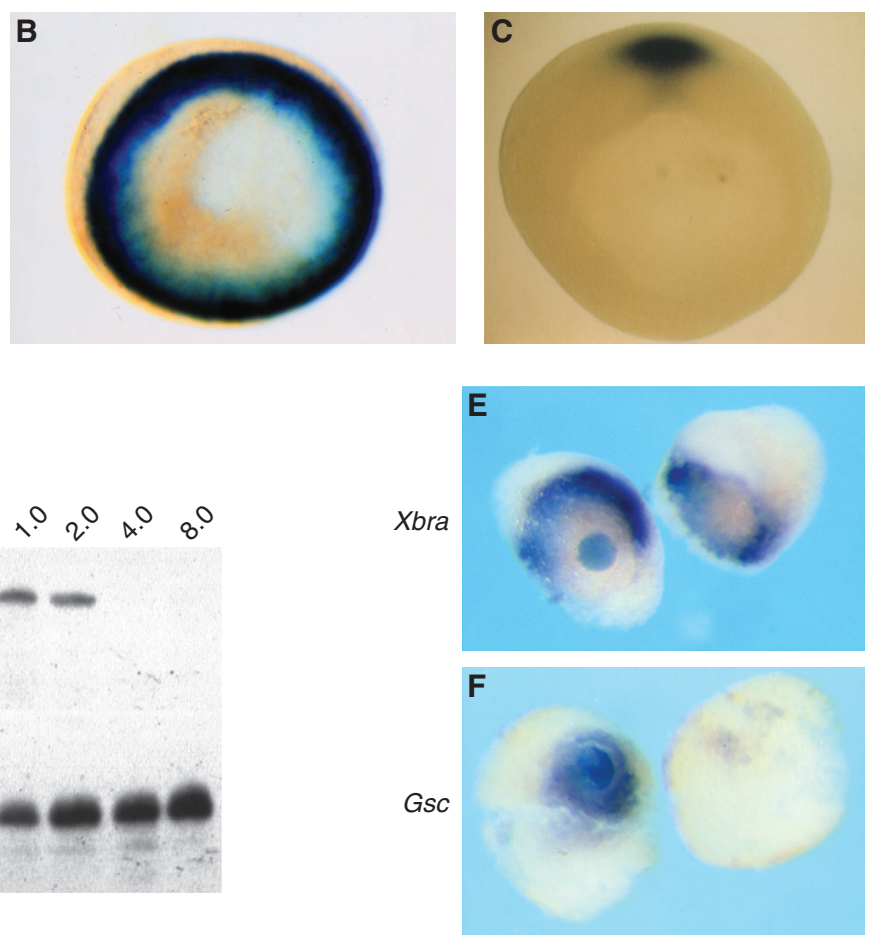

G

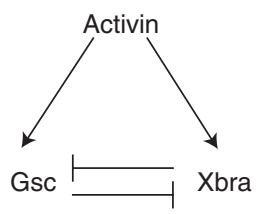

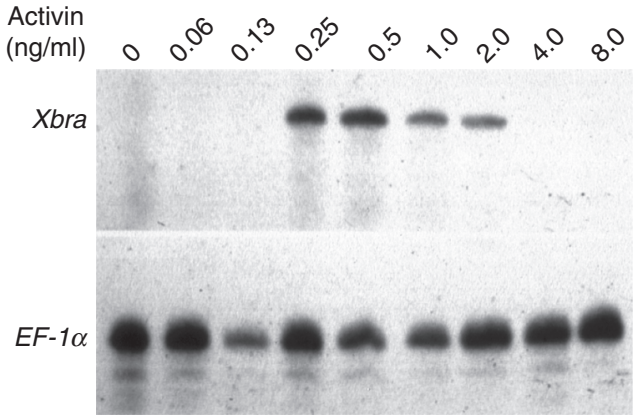

A

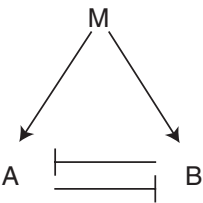

H

$$
\begin{aligned}
& \frac{d A}{d t}=\frac{k_{a}}{1+B^{\beta}} \cdot \frac{M^{\mu}}{1+M^{\mu}}-k d_{a} \cdot A \\
& \frac{d B}{d t}=\frac{k_{b}}{1+A^{\alpha}} \cdot \frac{M^{\mu}}{1+M^{\mu}}-k d_{b} \cdot B
\end{aligned}
$$

Figure 2. Threshold formation. ( $A, B)$ Normal expression of Xbra. (A) Sectioned in situ hybridization showing expression of Xbra in red. Animal pole is to the top and vegetal pole to the bottom. Photograph courtesy of Linda Essex and Michael Sargent. (B) Whole-mount in situ hybridization viewed from the vegetal pole. Notice expression of Xbra throughout the marginal zone. (C) Whole-mount in situ hybridization showing expression of goosecoid in the dorsal region of the embryo. Photograph by Susie Zoltewitz. (http://www. xenbase.org/xenbase/original/WWW/Marker_pages/organizer/goosecoid.html). (D) Differential expression of Xbra in response to different concentrations of activin. Disaggregated animal pole cells were exposed to the indicated concentrations of activin, reaggregated, and cultured until the equivalent of early gastrula stage 10. They were then assayed for expression of Xbra and EF-1 $\alpha$ by RNase protection. Note that Xbra is only activated by intermediate concentrations of activin. (E) Activation of Xbra by intermediate concentrations of activin. An activin-soaked bead was placed between two animal pole regions and cultured for 5 hours before being assayed for expression of Xbra. Note that Xbra is not activated close to the bead but at a distance, where the concentration of activin is at the appropriate level (Papin and Smith 2000). (F) Activation of goosecoid by high levels of activin. An identical experiment to that illustrated in $(E)$, but assaying for expression of goosecoid (Papin and Smith 2000). (G,H) An attempt to understand threshold formation. (G) Left-hand side illustrates that activin activates both goosecoid and Xbra, and the two gene products repress each other's expression. The same relationshiop with activin represented as $\mathrm{M}$ (morphogen) and goosecoid and Xbra as "A" and "B", respectively. $(H)$ Equations describing the rates of synthesis of A and B in response to M. M, A, and $\mathrm{B}$ represent the concentrations of each component, $\mathrm{k}_{\mathrm{a}}$ and $\mathrm{k}_{\mathrm{b}}$ are the synthesis rates of $\mathrm{A}$ and $\mathrm{B}$, respectively, $k d_{a}$ and $k d_{b}$ are the decay rates, $\alpha$ and $\mu$ are the cooperativities of repression of A by B and B by A, respectively, and $\mu$ is the cooperativity of induction by M (Saka and Smith 2007). 
(Cho et al. 1991). Dose-response experiments show that Xbra is activated only by intermediate concentrations of activin (and therefore resembles the white stripe of Wolpert's French flag model) (Fig. 2D,E), whereas goosecoid is induced only by high levels (and corresponds to the blue stripe) (Fig. 2F). Remarkably, 100 molecules of activin bound to a cell are sufficient to activate expression of Xbra, whereas 300 molecules are sufficient to induce goosecoid and lead to the repression of Xbra (Dyson and Gurdon 1998). These figures correspond to $2 \%$ and $6 \%$, respectively, of the total number of cell surface receptors.

These results, and others showing the dosedependent effects of mesoderm-inducing factors (Jones et al. 1995), suggest that gradients of such molecules might establish spatial patterns of gene expression in the early amphibian embryo. Further evidence that this might occur came from elegant experiments of John Gurdon and colleagues, who positioned beads previously soaked in activin between two animal pole regions. Such experiments revealed that activin can act over long range to induce gene expression in a concentration-dependent fashion (Gurdon et al. 1994) and that this longrange effect is not because of a "relay" involving a succession of short-range interactions (Reilly and Melton 1996) but rather to the direct action of activin derived from the bead (McDowell et al. 1997). The relay model suggests that cells adjacent to the signaling regions would themselves be caused to produce a signal, which would propagate in this way across a field of cells. Evidence arguing against the existence of such a mechanism came from the observation that cells expressing a constitutively active activin receptor could not signal to adjacent tissue (Jones et al. 1996). In addition, the use of labeled ligand revealed that activin can indeed form a gradient in the responding tissue (McDowell et al. 1997).

\section{EVIDENCE FOR GRADED SIGNALING: IN VIVO}

The experiments described previously indicate that, in artificial situations, activin and other
TGF- $\beta$ family members like the nodal-related proteins (Jones et al. 1995) can establish a gradient and that cells can respond to different morphogen concentrations by activating the expression of different genes. But does this occur in vivo? The answer to this question is complicated by the fact that there are many TGF- $\beta$ family mesoderm-inducing factors in the early Xenopus embryo, and it is not clear what their different roles are. It is possible, however, to draw some conclusions. The function of activin in the early Xenopus embryo can be inhibited by a particular dominantnegative receptor (Dyson and Gurdon 1997) or by specific antisense morpholino oligonucleotides (MOs) (Piepenburg et al. 2004). Injection of increasing amounts of $\mathrm{MOs}$ directed against activin caused first the downregulation of goosecoid expression and only later the down-regulation of Xbra (Piepenburg et al. 2004), arguing that a higher concentration of activin is required for expression of goosecoid than is required for Xbra. Knockdown of individual nodal-related proteins has little effect on the early specification of mesoderm (Toyoizumi et al. 2005), but it is possible to use "Cerberus-short," a truncated version of the secreted inhibitory molecule Cerberus (Bouwmeester et al. 1996), to inhibit the activities of all the nodal-related proteins, and experiments of this sort show that the nodal-related proteins are most active in dorsal regions of the embryo and least active ventrally (Agius et al. 2000). Finally, experiments making use of antibodies directed against an activated form of Smad2, a component of the activin/ nodal signal transduction pathway, reveal that levels of TGF- $\beta$ signaling are higher on the dorsal side of the embryo than on the ventral (Faure et al. 2000; Schohl and Fagotto 2002).

Together, these experiments indicate that members of the TGF- $\beta$ family, such as activin and the nodal-related proteins, are capable of acting as morphogens. The questions that need to be addressed are now: How do these morphogens exert their long-range effects and how do cells respond differentially to different morphogen concentrations? The rest of this article addresses these questions. 
J.C. Smith

\section{HOW ARE LONG-RANGE GRADIENTS OF MORPHOGENS ESTABLISHED?}

It is likely that long-range signaling occurs by different mechanisms in different developing systems. In particular, it seems probable that signaling in epithelial tissues, such as the Drosophila imaginal disk (Entchev et al. 2000; Strigini and Cohen 2000; Vincent and Dubois 2002) or the neuroectoderm of the zebrafish (Scholpp and Brand 2004), might differ from that in mesenchymal tissues such as the developing chick limb bud (Zeng et al. 2001; Dillon et al. 2003) or the early amphibian embryo. The analysis of long-range signaling in the early Xenopus embryo is therefore important for comparative and evolutionary reasons, as well as for its own sake.

As discussed above, the first analyses of signaling in Xenopus showed that the long-range effects of TGF- $\beta$ family members represent true long-range signaling, in the sense that signaling molecules themselves traversed the responding tissues. An understanding of the mechanism by which the molecules move across tissues has come from experiments in which the TGF- $\beta$ ligands themselves are made visible. In one series of experiments, beads soaked in TGF- $\beta 1$ were implanted between two animal pole regions, both of which expressed a type II TGF- $\beta$ receptor $(\mathrm{McD}$ owell et al. 2001). Use of a TGF- $\beta 1$ antibody revealed that a gradient of ligand could be observed across a distance of $150-200 \mu \mathrm{m}$. The TGF- $\beta 1$ signal colocalized with the TGF- $\beta$ IIR receptor, and indeed detection of TGF- $\beta 1$ required the presence of the receptor, suggesting that it caused the sequestration and concentration of the ligand. Ligand was only detectable in the extracellular space in these experiments, suggesting that the gradient does not form by transcytosis (repeated rounds of endocytosis and exocytosis), as has been suggested to occur in the Drosophila imaginal disk (Entchev et al. 2000; Gonzalez-Gaitan 2003). Furthermore, similarly shaped gradients were formed at $4^{\circ} \mathrm{C}$ and $23^{\circ} \mathrm{C}$. Because internalization of TGF- $\beta 1$ is significantly reduced at the lower temperature, this again indicates that transcytosis does not play a significant role in gradient formation.

As an alternative approach to visualizing signaling molecules in the developing amphibian embryo, Williams and colleagues created a cDNA encoding a version of Xnr2 that was tagged with enhanced green fluorescent protein (EGFP) (Williams et al. 2004). This modified form of Xnr2 retained its biological activity and was capable of exerting longrange effects. When animal pole tissue expressing this construct was juxtaposed with responding tissue, it was capable of activating gene expression in the adjacent cells and it was possible to visualize the movement of the tagged TGF- $\beta$ family member over several cell diameters (Fig. 3A). Consistent with previous work (McDowell et al. 2001), ligand appeared to move extracellularly, and no evidence was obtained for long-range signaling through transcytosis or through filopodia or cytonemes (Ramirez-Weber and Kornberg 1999).

Together, these results suggest that signaling molecules in the developing Xenopus embryo exert their long-range effects by traveling through extracellular space and not by traversing cells through transcytosis. Further evidence in favor of this idea comes from Gurdon, who interposed cells expressing a dominant-negative form of dynamin between activin-expressing cells and responding tissue (Kinoshita et al. 2006). Even though internalization was inhibited by the presence of DynaminK44E, the inducing signal was able to cross these cells to cause the nuclear translocation of Smad2-GFP, an effective reporter of activin signaling, in the wild-type responding tissue (Bourillot et al. 2002).

In future work, it will be important to discover what limits the range of signaling in the Xenopus embryo, and what determines the shape of the gradient. It is likely that signaling range is influenced in some way by interaction with the extracellular matrix, in a manner analogous to that in which BMP signaling range is regulated by type IV collagens in the Drosophila embryo (Wang et al. 2008). 

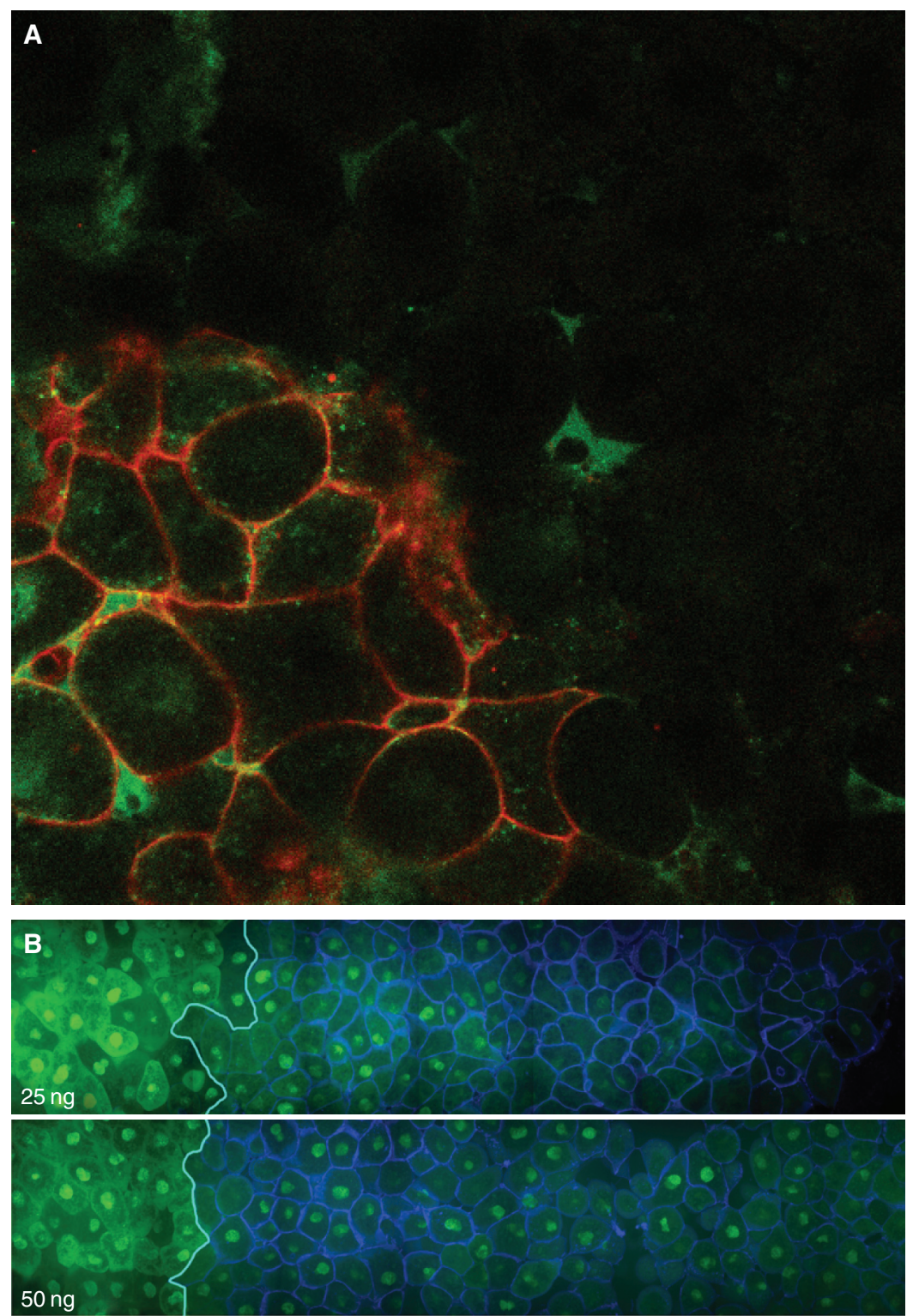

Figure 3. Following long-range signaling in the Xenopus embryo. (A) Animal pole tissue expressing enhanced green fluorescent protein (EGFP)-tagged Xnr2 (cells with red membranes) was juxtaposed with unlabeled tissue and cultured for 2.5 hours. Note the presence of EGFP fluorescence (green) in the unlabeled tissue. Photograph courtesy of Hugh Williams. $(B)$ Visualising activation of the activin signal transduction pathway by Smad2/4 bimolecular fluorescence complementation (BiFC). Animal pole regions derived from embryos previously injected with $25 \mathrm{ng}$ (top) or $50 \mathrm{ng}$ (bottom) mRNA encoding activin (left-hand side) were juxtaposed with tissue derived from embryos expressing GPI-CFP as a membrane-bound lineage marker (right-hand side). Both tissues were also expressing Smad2/4 BiFC constructs. Note nuclear fluorescence in cells at a distance from the source of activin, and that the range of signaling is greater when cells are expressing greater levels of activin. Photograph courtesy of Anja Hagemann. 
J.C. Smith

\section{HOW DO CELLS IN THE DEVELOPING AMPHIBIAN EMBRYO INTERPRET DIFFERENT MORPHOGEN CONCENTRATIONS?}

The second major challenge in coming to understand the role of graded signaling in pattern formation in the developing Xenopus embryo is to explain how different concentrations of morphogen activate the expression of different genes. This problem has been approached at several levels, but a satisfactory explanation has yet to emerge. As discussed above, quantitative work by Gurdon's group has indicated that 100 molecules of activin bound to a cell are sufficient to activate expression of Xbra, whereas 300 are necessary to activate goosecoid (Dyson and Gurdon 1998). This difference in the number of occupied receptors appears to be translated pari passu into the nuclear levels of Smad2, a key component of the activin signal transduction pathway. Thus, injection of $0.2 \mathrm{ng}$ of Smad2 RNA leads to the induction of Xbra, whereas injection of $0.6 \mathrm{ng}$ Smad2 RNA leads to the repression of Xbra and the activation of goosecoid. This threefold difference in levels of injected Smad2 RNA causes only a threefold difference in levels of nuclear Smad2, indicating that there is no nonlinear amplification of the extracellular signal between membrane and nucleus (Shimizu and Gurdon 1999). The intranuclear concentration of Smad2 is determined by the rate of flow of activated Smad 2 into the nucleus, where it undergoes degradation (Bourillot et al. 2002).

One important aspect of morphogen function is the ability of cells to "remember" the highest concentration of morphogen to which they have been exposed (Dyson and Gurdon 1998), a "ratchet" phenomenon that has also been termed "positional memory" (Smith 1979). This ability might allow cells to "buffer" fluctuating levels of an extracellular morphogen or allow the appropriate target genes to be activated even if levels of morphogen decline (Jullien and Gurdon 2005). One way in which this memory might be maintained is through the ability of embryonic cells to arrest movement of the internalized ligand-receptor complex before it reaches the lysosome, thus preventing its destruction and allowing signaling to continue unabated (Jullien and Gurdon 2005).

The direct translation of extracellular signal into intranuclear levels of Smad2 places the burden for differential gene activation on the regulatory regions of the genes in question: A simple model would have it that Xbra responds to lower doses of activin than does goosecoid. The promoters of both Xbra (Latinkic et al. 1997) and goosecoid (Watabe et al. 1995) have been studied, and as predicted, both respond to activin. It has not yet been possible, however, to ask whether the two genes respond differently to different concentrations of activin, partly because only limited portions of the regulatory regions of the two genes have been isolated, and partly because both genes respond to other signal transduction pathways. Xbra, for example, responds to FGF signaling (Smith et al. 1991; Green et al. 1992; Latinkic et al. 1997), and goosecoid to Wnt signaling (Watabe et al. 1995). In future work, it will be important to define more closely the activin-responsive elements of the two genes and to ask whether their quantitative responses to activin differ.

One simple model for the generation of differential gene expression in response to activin would have it that low concentrations of activin induce Xbra and high concentrations induce goosecoid; at high concentrations goosecoid might then repress the expression of Xbra. Thus, one important outcome of work on the Xbra promoter has been the identification of an element that causes the down-regulation of Xbra in response to goosecoid. The wildtype Xbra promoter responds to activin in a concentration-dependent manner that resembles the endogenous gene: It is activated by intermediate concentrations of activin and suppressed by high concentrations (Latinkic et al. 1997). Exogenous goosecoid protein is able to repress the activation of the Xbra reporter construct by intermediate concentrations of activin, but this repression is prevented by mutating two goosecoid binding sites between -174 and -152 nucleotides of the Xbra transcription start site (Latinkic et al. 1997). 
Although additional work suggests that goosecoid may not by the only gene product that represses Xbra at high concentrations of activin (Latinkic and Smith 1999; Papin and Smith 2000), the principle that interactions between activin responsive genes refine the transcriptional response to activin has been confirmed in other experiments. Thus, if gene activation in response to different concentrations of activin is analyzed shortly after activin treatment, Xbra and goosecoid are both seen to be expressed; refinement of their expression patterns might take as much as 3 hours (Papin and Smith 2000). And if treated animal pole regions are exposed to cycloheximide, an inhibitor of protein synthesis, refinement does not take place at all, again suggesting that interactions between gene products are responsible for generating thresholds (Papin and Smith 2000).

The simple network represented by the model above can be elaborated and formalized so as to ask whether its intuitive conclusions can withstand more rigorous analysis. To do so, Saka and Smith (Saka and Smith 2007) recognized not only that goosecoid represses expression of Xbra, but that Xbra, albeit indirectly, represses expression of goosecoid. By representing these observations in a formal network in which activin induces expression of both Xbra and goosecoid and in which $X b r a$ and goosecoid feed back on each other in a negative fashion (Fig. 2G,H), it was possible to show that such a scheme could convert a graded inducing signal into a binary output in which Xbra was on and goosecoid off or viceversa. Significantly, this mutual negative feedback system was capable of yielding sharp thresholds in response to increasing levels of activin, in a manner resembling the endogenous genes. The differential expression of Xbra and goosecoid in response to different concentrations of activin requires that the rates of synthesis of the two gene products are well balanced, and threshold formation is made more likely if the rates of degradation of Xbra and goosecoid differ.

Models such as this represent a great simplification of the real cell, and ultimately it will be necessary to model the complete genetic regulatory networks that underlie mesoderm formation in the early amphibian embryo (Loose and Patient 2004). This is a huge task, and it may not be feasible in the foreseeable future, but it may be possible to design a smaller network based on Xbra, targets of which have been identified through several screens (Tada et al. 1998; Saka et al. 2000; Tada and Smith 2000; Tada and Smith 2001). These Xenopus experiments have recently been complemented by work in the zebrafish that has used chromatin immunoprecipitation followed by microarray analysis to identify targets of no tail, a zebrafish ortholog of Xbra (Morley et al. 2009).

\section{OTHER SPECIES}

Members of the TGF- $\beta$ family play a role in mesoderm formation in other species, including mouse (Conlon et al. 1994; Vincent et al. 2003), chick (Seleiro et al. 1996; Shah et al. 1997), and zebrafish (Rebagliati et al. 1998; Feldman et al. 2000; Dougan et al. 2003; Liang and Rubinstein 2003), and at least in mouse (Vincent et al. 2003) and zebrafish (Chen and Schier 2001; Chen and Schier 2002; Solnica-Krezel 2003), it is clear that the body plan is specified by graded nodal signaling. Work in the zebrafish embryo has confirmed the impression gained from Xenopus (Green et al. 1990) and the chick embryo (Dessaud et al. 2007): that time of exposure to nodal is as important as the absolute concentration of ligand (Hagos and Dougan 2007). Thus, cells exposed to a uniform concentration of nodal for a long period of time adopt more marginal fates than cells exposed for a shorter period. Importantly, this provides a mechanism for "steepening" a gradient, for cells closer to the source will not only be exposed to a higher level of ligand than cells more distant, they will have been exposed to it for longer. This "integration" of time and concentration may underlie the spatial pattern of the Smad2 signal transduction pathway in the zebrafish embryo as revealed by use of a Smad2-Venus fusion protein and by $\mathrm{Smad} 2 / \mathrm{Smad} 4 \mathrm{BiFC}$ (Harvey and Smith 2009). Thus, Smad signaling 
J.C. Smith

in the zebrafish embryo, as in Xenopus, is higher dorsally, and this may occur because expression of the nodal ligand sqt begins on the dorsal side of the embryo and persists for longer in this region (Dougan et al. 2003).

\section{THE FUTURE}

It is now well established that gradients of TGF- $\beta$ family members regulate the spatial patterns of gene expression in the developing Xenopus embryo as well as in the embryos of other vertebrate species, and in this article I have outlined what we know about how this occurs. In the future, it will be important to take advantage of improved imaging technologies to observe morphogen function in real time and space. It may be possible, in a single embryo, to observe the progression of ligand (see Fig. 3A), the activation of a signal transduction pathway (Fig. 3B), and the induction of target genes. It may also be feasible to measure the concentrations of ligand and of various gene products. In this way, one will be able to test models of morphogen action more rigorously than is possible at present and thereby come to a definitive understanding of the spatial activation of gene expression in the developing embryo.

\section{ACKNOWLEDGMENTS}

Work in my laboratory is supported by the Wellcome Trust, the Medical Research Council, and the EU Networks of Excellence Cells into Organs and Endotrack.

\section{REFERENCES}

Agius E, Oelgeschlager M, Wessely O, Kemp C, De Robertis EM. 2000. Endodermal Nodal-related signals and mesoderm induction in Xenopus. Development 127: $1173-1183$.

Albano RM, Godsave SF, Huylebroeck D, Van Nimmen K, Isaacs HV, Slack JMW, Smith JC. 1990. A mesoderminducing factor produced by WEHI-3 murine myelomonocytic leukaemia cells is activin A. Development 110: 435-443.

Asashima M, Nakano H, Shimada K, Kinoshita K, Ishii K, Shibai H, Ueno N. 1990. Mesodermal induction in early amphibian embryos by activin A (erythroid differentiation factor). Wilhelm Roux' Archiv 198: 330-335.
Birsoy B, Kofron M, Schaible K, Wylie C, Heasman J. 2006. $\mathrm{Vg} 1$ is an essential signaling molecule in Xenopus development. Development 133: 15-20.

Boterenbrood EC, Nieuwkoop PD. 1973. The Formation of the Mesoderm in Urodelean Amphibians. V. Its Regional Induction by the Endoderm. Wilhelm Roux' Archiv 173: 319-332.

Bourillot PY, Garrett N, Gurdon JB. 2002. A changing morphogen gradient is interpreted by continuous transduction flow. Development 129: 2167-2180.

Bouwmeester T, Kim S, Sasai Y, Lu B, De Robertis EM. 1996. Cerberus is a head-inducing secreted factor expressed in the anterior endoderm of Spemann's organizer. Nature 382: $595-601$.

Chen Y, Schier AF. 2001. The zebrafish Nodal signal Squint functions as a morphogen. Nature 411: 607-610.

Chen Y, Schier AF. 2002. Lefty proteins are long-range inhibitors of squint-mediated nodal signaling. Curr Biol 12: 2124-2128.

Cho KW, Blumberg B, Steinbeisser H, De Robertis EM. 1991. Molecular nature of Spemann's organizer: the role of the Xenopus homeobox gene goosecoid. Cell 67: $1111-1120$.

Conlon FL, Lyons KM, Takaesu N, Barth KS, Kispert A, Herrmann B, Robertson EJ. 1994. A primary requirement for nodal in the formation and maintenance of the primitive streak in the mouse. Development 120: 1919-1928.

Dale L, Smith JC, Slack JM. 1985. Mesoderm induction in Xenopus laevis: a quantitative study using a cell lineage label and tissue-specific antibodies. J Embryol Exp Morphol 89: 289-312.

Dessaud E, Yang LL, Hill K, Cox B, Ulloa F, Ribeiro A, Mynett A, Novitch BG, Briscoe J. 2007. Interpretation of the sonic hedgehog morphogen gradient by a temporal adaptation mechanism. Nature 450: 717-720.

Dillon R, Gadgil C, Othmer HG. 2003. Short- and longrange effects of Sonic hedgehog in limb development. Proc Natl Acad Sci 100: 10152-10157.

Dougan ST, Warga RM, Kane DA, Schier AF, Talbot WS. 2003. The role of the zebrafish nodal-related genes squint and cyclops in patterning of mesendoderm. Development 130: 1837-1851.

Dyson S, Gurdon JB. 1997. Activin signalling has a necessary function in Xenopus early development. Curr Biol 7: $81-84$.

Dyson S, Gurdon JB. 1998. The interpretation of position in a morphogen gradient as revealed by occupancy of activin receptors. Cell 93: 557-568.

Entchev EV, Schwabedissen A, Gonzalez-Gaitan M. 2000. Gradient formation of the TGF-beta homolog Dpp. Cell 103: 981-991.

Faure S, Lee MA, Keller T, ten Dijke P, Whitman M. 2000. Endogenous patterns of TGFbeta superfamily signaling during early Xenopus development. Development 127: 2917-2931.

Feldman B, Dougan ST, Schier AF, Talbot WS. 2000. Nodal-related signals establish mesendodermal fate and trunk neural identity in zebrafish. Curr Biol 10: 531-534.

Fletcher RB, Harland RM. 2008. The role of FGF signaling in the establishment and maintenance of mesodermal gene expression in Xenopus. Dev Dyn 237: 1243-1254. 
Gonzalez-Gaitan M. 2003. Endocytic trafficking during Drosophila development. Mech Dev 120: 1265-1282.

Green JB, New HV, Smith JC. 1992. Responses of embryonic Xenopus cells to activin and FGF are separated by multiple dose thresholds and correspond to distinct axes of the mesoderm. Cell 71: 731-739.

Green JB, Smith JC. 1990. Graded changes in dose of a Xenopus activin A homologue elicit stepwise transitions in embryonic cell fate. Nature 347: 391-394.

Green JB, Smith JC, Gerhart JC. 1994. Slow emergence of a multithreshold response to activin requires cellcontact-dependent sharpening but not prepattern. Development 120: 2271-2278.

Green JBA, Howes G, Symes K, Cooke J, Smith JC. 1990. The biological effects of XTC-MIF: quantitative comparison with Xenopus bFGF. Development 108: 229-238.

Gurdon JB, Harger P, Mitchell A, Lemaire P. 1994. Activin signalling and response to a morphogen gradient. Nature 371: 487-492.

Hagos EG, Dougan ST. 2007. Time-dependent patterning of the mesoderm and endoderm by Nodal signals in zebrafish. BMC Dev Biol 7: 22.

Harvey SA, Smith JC. 2009. Visualisation and Quantification of Morphogen Gradient Formation in the Zebrafish. PLoS Biol 7: e101.

Heasman J. 2006. Patterning the early Xenopus embryo. Development 133: 1205-1217.

Isaacs HV, Tannahill D, Slack JM. 1992. Expression of a novel FGF in the Xenopus embryo. A new candidate inducing factor for mesoderm formation and anteroposterior specification. Development 114: 711-720.

Jones CM, Armes N, Smith JC. 1996. Signalling by TGF-beta family members: short-range effects of Xnr-2 and BMP-4 contrast with the long-range effects of activin. Curr Biol 6: $1468-1475$.

Jones CM, Kuehn MR, Hogan BL, Smith JC, Wright CV 1995. Nodal-related signals induce axial mesoderm and dorsalize mesoderm during gastrulation. Development 121: $3651-3662$

Joseph EM, Melton DA. 1997. Xnr4: A Xenopus nodalrelated gene expressed in the Spemann Organiser. Dev Biol 184: 367-372.

Jullien J, Gurdon J. 2005. Morphogen gradient interpretation by a regulated trafficking step during ligandreceptor transduction. Genes Dev 19: 2682-2694.

Kimelman D, Kirschner M. 1987. Synergistic induction of mesoderm by FGF and TGF-beta and the identification of an mRNA coding for FGF in the early Xenopus embryo. Cell 51: 869-877.

Kinoshita T, Jullien J, Gurdon JB. 2006. Two-dimensional morphogen gradient in Xenopus: boundary formation and real-time transduction response. Dev Dyn 235: 3189-3198.

Kroll KL, Amaya E. 1996. Transgenic Xenopus embryos from sperm nuclear transplantations reveal FGF signaling requirements during gastrulation. Development 122: 3173-3183.

Latinkic BV, Smith JC. 1999. Goosecoid and mix.1 repress Brachyury expression and are required for head formation in Xenopus. Development 126: 1769-1779.
Latinkic BV, Umbhauer M, Neal KA, Lerchner W, Smith JC, Cunliffe V. 1997. The Xenopus Brachyury promoter is activated by FGF and low concentrations of activin and suppressed by high concentrations of activin and by paired-type homeodomain proteins. Genes Dev 11: 3265-3276.

Lewis J, Slack JM, Wolpert L. 1977. Thresholds in development. J Theor Biol 65: 579-590.

Liang JO, Rubinstein AL. 2003. Patterning of the zebrafish embryo by nodal signals. Curr Top Dev Biol 55: 143-171.

Loose M, Patient R. 2004. A genetic regulatory network for Xenopus mesendoderm formation. Dev Biol 271: 467-478.

McDowell N, Gurdon JB, Grainger DJ. 2001. Formation of a functional morphogen gradient by a passive process in tissue from the early Xenopus embryo. Int J Dev Biol 45: 199-207.

McDowell N, Zorn AM, Crease DJ, Gurdon JB. 1997. Activin has direct long-range signalling activity and can form a concentration gradient by diffusion. Curr Biol 7: 671-681.

Morley RH, Lachani K, Keefe D, Gilchrist MJ, Flicek P, Smith JC, Wardle FC. 2009. A gene regulatory network directed by zebrafish No tail accounts for its roles in mesoderm formation. Proc Natl Acad Sci 106: 3829-3834.

Naiche LA, Harrelson Z, Kelly RG, Papaioannou VE. 2005. T-box genes in vertebrate development. Annu Rev Genet 39: $219-239$.

Nieuwkoop PD. 1969. The formation of mesoderm in Urodelean amphibians. I. Induction by the endoderm. Wilhelm Roux' Archiv 162: 341-373.

Nieuwkoop PD, Faber J. 1956. Normal table of Xenopus laevis (Daudin). North Holland, Amsterdam.

Papin C, Smith JC. 2000. Gradual refinement of activin-induced thresholds requires protein synthesis. Dev Biol 217: 166-172.

Piepenburg O, Grimmer D, Williams PH, Smith JC. 2004. Activin redux: Specification of mesodermal pattern in Xenopus by graded concentrations of endogenous activin B. Development 131: 4977-4986.

Ramirez-Weber FA, Kornberg TB. 1999. Cytonemes: cellular processes that project to the principal signaling center in Drosophila imaginal discs. Cell 97: 599-607.

Rebagliati MR, Toyama R, Fricke C, Haffter P, Dawid IB. 1998. Zebrafish nodal-related genes are implicated in axial patterning and establishing left-right asymmetry. Dev Biol 199: 261-272.

Reilly KM, Melton DA. 1996. Short-range signaling by candidate morphogens of the TGF beta family and evidence for a relay mechanism of induction. Cell 86: 743-754.

Saka Y, Smith JC. 2007. A mechanism for the sharp transition of morphogen gradient interpretation in Xenopus. BMC Dev Biol 7: 47

Saka Y, Tada M, Smith JC. 2000. A screen for targets of the Xenopus T-box gene Xbra. Mech Dev 93: 27-39.

Schohl A, Fagotto F. 2002. Beta-catenin, MAPK and Smad signaling during early Xenopus development. Development 129: 37-52.

Scholpp S, Brand M. 2004. Endocytosis controls spreading and effective signaling range of Fgf8 protein. Curr Biol 14: $1834-1841$. 
J.C. Smith

Seleiro EA, Connolly DJ, Cooke J. 1996. Early developmental expression and experimental axis determination by the chicken Vg1 gene. Curr Biol 6: 1476-1486.

Shah SB, Skromne I, Hume CR, Kessler DS, Lee KJ, Stern CD, Dodd J. 1997. Misexpression of chick Vgl in the marginal zone induces primitive streak formation. Development 124: 5127-5138.

Shimizu K, Gurdon JB. 1999. A quantitative analysis of signal transduction from activin receptor to nucleus and its relevance to morphogen gradient interpretation. Proc Natl Acad Sci 96: 6791-6796.

Slack JM, Darlington BG, Heath JK, Godsave SF. 1987. Mesoderm induction in early Xenopus embryos by heparin-binding growth factors. Nature 326: 197-200.

Smith JC. 1979. Evidence for a positional memory in the development of the chick wing bud. J Embryol Exp Morphol 52: 105-113.

Smith JC, Dale L, Slack JM. 1985. Cell lineage labels and region-specific markers in the analysis of inductive interactions. J Embryol Exp Morphol 89 Suppl: 317-331.

Smith JC, Price BM, Green JB, Weigel D, Herrmann BG. 1991. Expression of a Xenopus homolog of Brachyury ( $\mathrm{T})$ is an immediate-early response to mesoderm induction. Cell 67: 79-87.

Smith JC, Price BMJ, Van Nimmen K, Huylebroeck D. 1990. Identification of a potent Xenopus mesoderminducing factor as a homologue of activin A. Nature 345: $732-734$.

Solnica-Krezel L. 2003. Vertebrate development: taming the nodal waves. Curr Biol 13: R7-9.

Strigini M, Cohen SM. 2000. Wingless gradient formation in the Drosophila wing. Curr Biol 10: 293-300.

Sudarwati S, Nieuwkoop PD. 1971. Mesoderm formation in the Anuran Xenopus laevis (Daudin). Wilhelm Roux' Archiv 166: 189-204.

Sun BI, Bush SM, Collins-Racie LA, LaVallie ER, DiBlasio-Smith EA, Wolfman NM, McCoy JM, Sive HL. 1999. derrière: a TGF-beta family member required for posterior development in Xenopus. Development 126: $1467-1482$.

Tada M, Casey ES, Fairclough L, Smith JC. 1998. Bix1, a direct target of Xenopus T-box genes, causes formation of ventral mesoderm and endoderm. Development 125: 3997-4006.

Tada M, Smith JC. 2000. Xwnt11 is a target of Xenopus Brachyury: regulation of gastrulation movements via
Dishevelled, but not through the canonical Wnt pathway. Development 127: 2227-2238.

Tada M, Smith JC. 2001. T-targets: clues to understanding the functions of T-box proteins. Dev Growth Differ 43: $1-11$.

Takahashi S, Yokota C, Takano K, Tanegashima K, Onuma Y, Goto J, Asashima M. 2000. Two novel nodal-related genes initiate early inductive events in Xenopus Nieuwkoop center. Development 127: 5319-5329.

Toyoizumi R, Ogasawara T, Takeuchi S, Mogi K. 2005. Xenopus nodal related-1 is indispensable only for left-right axis determination. Int J Dev Biol 49: 923-938.

Vincent JP, Dubois L. 2002. Morphogen transport along epithelia, an integrated trafficking problem. Dev Cell 3: 615-623.

Vincent SD, Dunn NR, Hayashi S, Norris DP, Robertson EJ. 2003. Cell fate decisions within the mouse organizer are governed by graded Nodal signals. Genes Dev 17: $1646-1662$.

Vogt W. 1929. Gestaltunganalyse am Amphibienkeim mit örtlicher Vitalfärbung. II. Gastrulation und Mesodermbildung bei Urodelen und Anuren. Wilhelm Roux' Archiv 120: 384-706.

Wang X, Harris RE, Bayston LJ, Ashe HL. 2008. Type IV collagens regulate BMP signalling in Drosophila. Nature 455: $72-77$.

Watabe T, Kim S, Candia A, Rothbacher U, Hashimoto C, Inoue K, Cho KW. 1995. Molecular mechanisms of Spemann's organizer formation: conserved growth factor synergy between Xenopus and mouse. Genes Dev 9: 3038-3050.

Weeks DL, Melton DA. 1987. A maternal mRNA localized to the vegetal hemisphere in Xenopus eggs codes for a growth factor related to TGF-beta. Cell 51: 861-867.

Williams PH, Hagemann A, Gonzalez-Gaitan M, Smith JC. 2004. Visualizing long-range movement of the morphogen Xnr2 in the Xenopus embryo. Curr Biol 14: 1916-1923.

Wolpert L. 1969. Positional information and the spatial pattern of cellular differentiation. J Theor Biol 25: 1-47.

Zeng X, Goetz JA, Suber LM, Scott WJ Jr, Schreiner CM, Robbins DJ. 2001. A freely diffusible form of Sonic hedgehog mediates long-range signalling. Nature 411: $716-720$. 


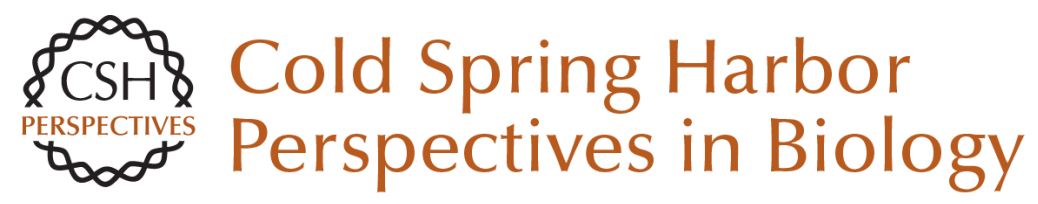

\section{Forming and Interpreting Gradients in the Early Xenopus Embryo}

James C. Smith

Cold Spring Harb Perspect Biol 2009; doi: 10.1101/cshperspect.a002477

Subject Collection Generation and Interpretation of Morphogen Gradients

Regulation of Organ Growth by Morphogen

Gradients

Gerald Schwank and Konrad Basler

Signaling Gradients during Paraxial Mesoderm

Development

Alexander Aulehla and Olivier Pourquié

Morphogen Gradient Formation

Ortrud Wartlick, Anna Kicheva and Marcos

González-Gaitán

Nodal Morphogens

Alexander F. Schier

Gradients and the Specification of Planar Polarity in the Insect Cuticle

David Strutt

Vertebrate Limb Development: Moving from

Classical Morphogen Gradients to an Integrated

4-Dimensional Patterning System Jean-Denis Bénazet and Rolf Zeller

Establishing and Interpreting Graded Sonic Hedgehog Signaling during Vertebrate Neural

Tube Patterning: The Role of Negative Feedback Vanessa Ribes and James Briscoe

Systems Biology of the Self-regulating

Morphogenetic Gradient of the Xenopus Gastrula Jean-Louis Plouhinec and E. M. De Robertis
Gradients in Planarian Regeneration and Homeostasis

Teresa Adell, Francesc Cebrià and Emili Saló

Shaping Morphogen Gradients by Proteoglycans Dong Yan and Xinhua Lin

Forming Patterns in Development without Morphogen Gradients: Scattered Differentiation and Sorting Out

Robert R. Kay and Christopher R.L. Thompson

Robust Generation and Decoding of Morphogen Gradients

Naama Barkai and Ben-Zion Shilo

Models for the Generation and Interpretation of

Gradients

Hans Meinhardt

Graded Dorsal and Differential Gene Regulation in the Drosophila Embryo

Gregory T. Reeves and Angelike Stathopoulos

Chemical Gradients and Chemotropism in Yeast Robert A. Arkowitz

Gradients in the Brain: The Control of the

Development of Form and Function in the

Cerebral Cortex

Stephen N. Sansom and Frederick J. Livesey

For additional articles in this collection, see http://cshperspectives.cshlp.org/cgi/collection/

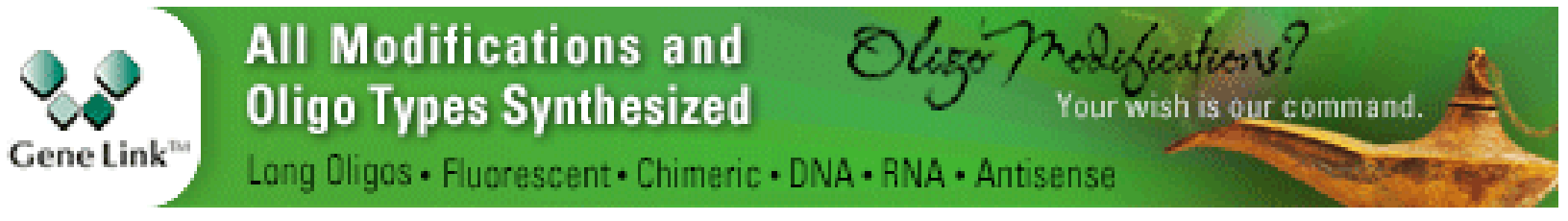

